\title{
Śledzenie (śladów) sensu. Tekst i lektura w hermeneutyce ponowoczesnej
}

\author{
Patryk Szaj
}

Rozumienie tekstu nigdy nie jest rozumieniem tego, co chciało się rozumieć - na tym polega zasadnicza negatywność doświadczenia hermeneutycznego ${ }^{1}$.

Hermeneutyka ponowoczesna, zwana także radykalną, wyrasta w znacznej mierze z refleksji postmodernistycznej. Jest to dziedzictwo tyleż szacowne, co kłopotliwe, kogóż bowiem częściej niż postmodernistów oskarżano o propagowanie frywolności interpretacyjnej, wyrażającej się w haśle anything goes (do którego czasem tylko dodawano obostrzenie: if it works)? Ale radykalnohermeneutyczna relacja $z$ tekstem bynajmniej nie jest dowolna, przeciwnie - spełnić zadanie hermeneutyczne z całym radykalizmem, to właśnie trzymać się „blisko tekstu”. Rzecz w tym, że zarówno sam „tekst”, jak i „bliskość” są tu pojmowane specyficznie.

\section{„Dać sobie coś powiedzieć" - tekst w hermeneutyce Gadamerowskiej} O tym, że tekst jest dla hermeneutyki ważny, mówi figura koła hermeneutycznego, która w swym najpopularniejszym wydaniu głosi, że rozumienie przebiega zawsze od części do całości i od całości do części, nakładając tym samym na czytelnika wymóg dokładnego śledzenia poszczególnych partii, fragmentów, warstw czy też poziomów tekstu i weryfikowania na ich podstawie zarysowującego się w trakcie lektury obrazu całości. Ale koło hermeneutyczne mówi też, że dla hermeneutyki równie ważny jest czytelnik: jak na gruncie ontologicznym wszelkie rozumienie jest zawsze już samorozumieniem², tak na gruncie interpretacyjnym - czego najdonioślejszą lekcję dał Hans-Georg Gadamer - w obliczu rozumianego tekstu rozumiem samego siebie, w toku lektury następuje wzajemna wymiana pytań i odpowiedzi między tekstem a mną, swoista „rozmowa”, w której - to już Paul Ricoeur - „tekst i czytelnik kolejno się do siebie zbliżają i od siebie oddalają"4.

\footnotetext{
${ }^{1}$ P. Kuligowski, Humanistyka jako hermeneutyka, Wrocław 2007, s. 290-291 (cyt. za: K. Szkaradnik, Czy podejście hermeneutyczne jest interpretacyjnym wytrychem? Diagnoza i propozycja w kontekście wspótczesnej prozy, tekst złożony w redakcji „Przestrzeni Teorii”, udostępniony mi przez autorkę na prawach rękopisu).

2 Zob. M. Heidegger, Bycie i czas, przeł. B. Baran, Warszawa 2010, s. 202-209.

${ }^{3}$ Zob. H.-G. Gadamer, Prawda i metoda. Zarys hermeneutyki filozoficznej, przeł. B. Baran, Warszawa 2016, s. $493-517$.

${ }^{4}$ P. Ricoeur, Czas i opowieść, t. 3, przeł. U. Zbrzeźniak, Kraków 2008, s. 321-322.
} 
Dzieje się tak ze względu na „naturę” tekstu, którego hermeneutyczne rozumienie przedstawił Gadamer w szkicu Tekst i interpretacja: „hermeneutyczne odniesienie do pojęcia tekstu odnajdujemy w konkretnym zastosowaniu wszędzie tam, i tylko tam, gdzie z wyjściowym domniemaniem sensu przystępuje się do jakiejś faktyczności, która nie spełnia bezkonfliktowo oczekiwań odnośnie do tego sensu. [...] Z punktu widzenia hermeneutycznego - który jest punktem widzenia każdego czytelnika - tekst jest tylko wytworem pośrednim [Zwischenpro$d u k t]$, pewną fazą w procesie porozumienia [...]" "Wynikają stąd co najmniej trzy wnioski: po pierwsze, „sens” jest tym, wokół czego ogniskuje się hermeneutyczne czytanie tekstu, po drugie, ów „sens” jest czymś zrazu nieoczywistym, czymś, co dopiero należy uobecnić w procesie rozumienia, po trzecie wreszcie, tekst jawi się jedynie jako epifenomen, pełniący podrzędną funkcję w owym procesie uobecniania ${ }^{6}$. Jak jednak proces ten się odbywa? To właśnie okazuje się kwestią niejednoznaczną, i to już na gruncie samej hermeneutyki Gadamerowskiej.

Z jednej strony autor Prawdy i metody, mimo że - jak widzimy - dostrzega problematyczność założenia o „wyjściowym domniemaniu sensu”, wyraźnie podkreśla konieczność (i możliwość) jego pełnego u-obecnienia, ilekroć powtarza, że każda forma hermeneutyki jest „formą przezwyciężania uświadomionego podejrzenia”, ilekroć wskazuje na „rekonstrukcję i integrację jako zadanie hermeneutyczne”, ilekroć wreszcie przekonuje, że na końcu procesu interpretacji „interpretator, który podał swoje racje, znika - tekst przemawia sam" ", jakby rzeczywiście miało dojść do cudownego ujednoznacznienia sensów przekazywanych przez dzieło. W istocie, Gadamer z całą stanowczością podkreśla, że „tylko to jest zrozumiałe, co rzeczywiście prezentuje sobą pełną jedność sensu” ${ }^{10}$.

Z drugiej jednak strony, sam autor Aktualności piękna „osłabia” te finalistyczne roszczenia: „Nie znaczy to, że nieokreślone oczekiwanie sensu, które sprawia, iż dzieło staje się dla nas ważne, może za każdym razem znaleźć całkowite spełnienie, tak byśmy ze zrozumieniem i z aprobatą mogli sobie przyswoić pełny sens. [...] Oczekiwanie, że można w pojęciu zebrać sensowne treści, jakimi sztuka do nas przemawia, zawsze niebezpiecznie pozostawiało sztukę gdzieś w tyle”11. Podobną dwuznacznością naznaczony jest ideał „fuzji horyzontów”, który bynajmniej nie stanowi jakiegoś telosu rozumienia, ale jest czymś procesualnym, chwilowym, wciąż na nowo de- i rekonstruowanym ${ }^{12}$, tak że pojąć go można raczej jako ideę regulatywną niż konstytutywną, podkreślającą zresztą prymat różnicy i nieporozumienia nad tożsamością i zrozumieniem: „Ten, kto rozumie, musi rozumieć inaczej, jeśli w ogóle pragnie rozumieć”13.

A zatem z jednej strony skupianie sensu, z drugiej - wprost przeciwnie - jego ciągłe rozpraszanie. Wydaje się, że oscylowanie hermeneutyki Gadamerowskiej wokół tych dwóch biegunów

\footnotetext{
${ }^{5}$ H.-G. Gadamer, Tekst i interpretacja, przeł. P. Dehnel, [w:] tegoż, Język i rozumienie, Warszawa 2003, s. 113-114.

${ }^{6} \mathrm{Za}$ tę uwagę dziękuję Katarzynie Szkaradnik.

${ }^{7}$ H.-G. Gadamer, Hermeneutyka podejrzenia, przeł. P. Czapliński, „Pamiętnik Literacki” 1992, z. 1, s. 172.

${ }^{8}$ Zob. tegoż, Prawda i metoda..., s. 239-246.

${ }^{9}$ Tegoż, Tekst $\mathrm{i}$ interpretacja, s. 141.

${ }^{10}$ Tegoż, Koło jako struktura rozumienia, [w:] Wokót rozumienia. Studia i szkice z hermeneutyki, wybór i przekł. G. Sowiński, Kraków 1993, s. 231.

${ }^{11}$ Tegoż, Aktualność piękna. Sztuka jako gra, symbol i święto, przeł. K. Krzemieniowa, Warszawa 1993, s. 44-45.

${ }^{12}$ Por. P. Dybel, Oblicza hermeneutyki, Kraków 2012, s. 340.

${ }^{13}$ H.-G. Gadamer, Romantyzm, hermeneutyka, dekonstrukcja, [w:] tegoż, Język i rozumienie, s. 148.
} 
rozumienia wynika bezpośrednio z postawy czytelnika, który pragnie rozumieć, ale chce też oddać sprawiedliwość samemu tekstowi. Stąd bierze się także sprzeciw Gadamera wobec metody - chcieć zrozumieć tekst to dostrzec jego pojedynczość, niepowtarzalność, jego wymykanie się metodom, które wprawdzie mogą pomóc w zrozumieniu, naświetlając go z jednej czy z drugiej strony, ale których w żadnym wypadku nie należy przykładać do niego na ślepo ${ }^{14}$. Tym bowiem, o co toczy się hermeneutyczna gra $\mathrm{z}$ tekstem, jest jego inność będąca warunkiem możliwości dokonania rearanżacji egzystencjalnej czytelnika: „nie można zrozumieć, jeśli [...] się nie chce dać sobie czegoś powiedzieć”, „W radosnej i strasznej grozie dzieło sztuki oznajmia: To jesteś ty - ale mówi także: Musisz zmienić swoje życie"15.

\section{„Skupić całość tekstu w prawdę sensu” - Derridiańska krytyka hermeneutyki}

Ów deklarowany przez Gadamera szacunek wobec inności tekstu nie obronił jednak hermeneutyki przed krytyką ze strony Jacques'a Derridy, wedle którego całe przedsięwzięcie hermeneutyczne okazuje się chybione ze względu na - jak to ujęła Anna Burzyńska - „milczące założenie", że tekst posiada sens ${ }^{16}$. Zarzut ten - rozmaicie formułowany, ale sprowadzający się właśnie do tego niepodważalnego aksjomatu „zadanego do uobecnienia” sensu - powtarzał Derrida zarówno podczas publicznej dyskusji z Gadamerem w 1981 r. $^{17}$, jak i w wielu swoich szkicach. Lektura hermeneutyczna przybiera bowiem jego zdaniem postać lektury „transcendentnej”, tzn. odsyłającej zawsze na zewnątrz samego tekstu, w stronę (fundującego go, uprzedniego względem niego) sensu. Hermeneutyczne „trzymanie się blisko tekstu” okazuje się zatem pozorne, gdyż tak naprawdę chodzi w nim o to, co poza samym tekstem. Taki pozorny charakter miałaby np. zasada hermeneutyki protestanckiej, sola Scriptura, zdaniem Pawła Dybla implikująca „rygorystyczne podejście do litery tekstu”"18, ale fundująca przecież to „literalne” odczytanie na zewnętrznym autorytecie Boskiego natchnienia. Jak mówi Derrida, w takim rozumieniu „czytanie i pisanie, wytwarzanie i interpretowanie znaków, tekst w ogóle, tekst jako tkanka znaków, dają się sprowadzić do postaci wtórnej. Poprzedza je prawda albo sens ukonstytuowane już przez żywioł logosu i w tym żywiole”19. „Rozumieć” to zatem „skupić całość tekstu w prawdę sensu"20.

\footnotetext{
${ }^{14}$ Zob. tegoż, Czy poeci umilknq̨?, przeł. M. Łukasiewicz, Bydgoszcz 1998, s. 160. Podobny aspekt odnaleźć można też w przekonaniu Ricoeura, dla którego hermeneutyka przemienia się w metodę dopiero wtedy, gdy jako taka zostanie usankcjonowana przez sam tekst (bądź rozumiany byt): „za każdym razem każda hermeneutyka odkrywa jakiś aspekt egzystencji, który ją uzasadnia jako metodę". P. Ricoeur, Egzystencja i hermeneutyka. Rozprawy o metodzie, przeł. K. Tarnawski, Warszawa 1985, s. 199.

${ }^{15}$ H.-G. Gadamer, Estetyka i hermeneutyka, [w:] tegoż, Rozum, słowo, dzieje. Szkice wybrane, Warszawa 2000, s. 138, 141.

${ }^{16}$ Zob. A. Burzyńska, Jak czytali dekonstrukcjoniści, [w:] tejże, Anty-teoria literatury, Kraków 2006, s. 275.

${ }^{17} \mathrm{Na}$ temat paryskiego spotkania Derridy i Gadamera zob. np. K. Bartoszyński, Hermeneutyka a dekonstrukcja. Hans-Georg Gadamer i Jacques Derrida wobec poezji, [w:] tegoż, Kryzys czy trwanie powieści. Studia literaturoznawcze, Kraków 2004; P. Dybel, Poza dialektyką? Spór Gadamera z Derridą, [w:] tegoż, Granice rozumienia i interpretacji. O hermeneutyce Hansa-Georga Gadamera, Kraków 2004; P. Dehnel, Dekonstrukcja a hermeneutyka, [w:] tegoż, Dekonstrukcja - rozumienie - interpretacja. Studia z filozofii współczesnej i nie tylko, Kraków 2006.

${ }^{18}$ Zob. P. Dybel, Oblicza hermeneutyki, s. 120-127.

${ }^{19}$ J. Derrida, O gramatologii, przeł. B. Banasiak, Łódź 2011, s. 39

${ }^{20}$ Tegoż, Positions, Paris 1972, s. 44. Cyt. za: B. Banasiak, Derrida-Nietzsche(-go sobie), [w:] J. Derrida, Ostrogi. Style Nietzschego, przeł. B. Banasiak, Łódź 2012, s. 10 (w polskim przekładzie Pozycji brak cytowanego przez Banasiaka ustępu).
} 
Warto jednak pamiętać, że hermeneutyka nie jest tu główną winowajczynią, ale jedynie spadkobierczynią logocentrycznej tradycji filozofii metafizycznej, którą - we własnym mniemaniu - stara się przekroczyć (szacunek dla inności tekstu), ale w której wciąż tkwi jedną nogą (tekst przekazuje mi jakiś sens). Kiedy Derrida mówił „hermeneutyka”, nie odnosząc tej nazwy do konkretnego przedstawiciela refleksji hermeneutycznej, miał z reguły na myśli tradycję filozofii zachodniej, którą za Heideggerem nazywał „onto-hermeneutyczną”, a w której daleko bardziej niż hermeneutyka w wydaniu Gadamerowskim czy Ricoeurowskim tkwiły np. strukturalizm czy semiotyka Ferdinanda de Saussure’a. Jest to opisana w „klasycznym” artykule Struktura, znak i gra $w$ dyskursie nauk humanistycznych tradycja zabezpieczania wolnej gry struktury poprzez wpisywanie jej w jakąś centralną/logocentryczną, a jednocześnie sytuującą się na zewnątrz samej struktury, stabilizującą ideę ${ }^{21}$. Na przykład hermeneutyczny „sens”, ale też semiotyczne „znaczone” albo - najogólniej rzecz ujmując - „transcendentalne signifié”.

W odpowiedzi na to „skupianie całości tekstu w prawdę sensu” Derrida nie proponował jednak - jak nadal często mu się imputuje - pełnej dowolności interpretacyjnej. Przeciwnie, lektura dekonstrukcyjna trzyma się bardzo blisko tekstu, można by nawet powiedzieć, że jest ona sztuką mikrolektury par excellence ${ }^{22}$ : „U Joyce’a potrafiłem jedynie wydzielić dwa słowa (He war albo yes, yes); u Celana jedno słowo obce (Shibboleth); u Blanchota jedno słowo i dwa homonimy (pas). Nigdy jednak nie twierdziłbym, że «przeczytałem» lub zaproponowałem ogólną lekturę tych dzieł"23. Listę tę, jak wiadomo, uzupełnić by można wieloma przykładami: „hymen” u Mallarmégo, „suplement” u Rousseau, „farmakon” u Platona, „parergon” u Kanta, „skandal” zakazu kazirodztwa u Lévi-Straussa... To skupienie Derridy na pojedynczych wyimkach z czytanych (ale nie prze-czytanych) przez niego tekstów stanowi oczywiście ważny element jego strategii, polegającej na podkreślaniu roli pisma i jego znaczeniorodności, która rozgrywa się nie na zewnątrz tekstu, na poziomie znaczonego (np. znaczonego sensu), ale właśnie w jego wnętrzu, na poziomie znaczących. Na dochowaniu wierności tej grze znaczących polega lektura, którą autor O gramatologii nazywał „nietranscendentną”, nieporzucającą zainteresowania dla znaczącego, formy, języka, materii, z jakiej ustrukturyzowany został tekst. W przeciwieństwie jednak do tzw. dekonstrukcjonistów amerykańskich (resp. szkoły z Yale), dla których „permanentna parabaza alegorii” oznaczać by miała całkowite zawieszenie logiki i otwarcie przestrzeni dla „aberracji referencjalnej”"24, Derrida podkreślał jednoczesną niemożliwość niepodejmowania lektury transcendentnej: „tekst sam z siebie nie potrafi uniknąć poddania się lekturze «transcendentnej». [...] Tego momentu «transcendencji» nie sposób uniknąć, choć może on być bardzo skomplikowany lub powikłany"25.

\footnotetext{
${ }^{21}$ Zob. J. Derrida, Struktura, znak i gra w dyskursie nauk humanistycznych, przeł. W. Kalaga, „Pamiętnik Literacki” 1986, nr 2 .

${ }^{22}$ Podkreślają to bardzo wyraźnie tacy interpretatorzy Derridy, jak Christopher Norris („[dekonstrukcja jest] aktywnością czytania ściśle związaną z tekstami, które bada" - Deconstruction and Practice, London-New York 1993, s. 31) czy John D. Caputo (zob. Deconstruction in a Nutshell. A Conversation with Jacques Derrida, New York 1997, s. 74-81). Jako jednego z „patronów” swojego projektu mikrologii traktował też Derridę Aleksander Nawarecki (zob. Miniatura i mikrologia literacka, t. 1-2, red. A. Nawarecki, Katowice 2000-2001).

${ }^{23}$ Ta dziwna instytucja zwana literatura. Z Jacquesem Derrida rozmawia Derek Attridge, przeł. M.P. Markowski, „Literatura na Świecie” 1998, nr 11-12, s. 210).

${ }^{24}$ Zob. P. de Man, Alegorie czytania. Język figuralny u Rousseau, Nietzschego, Rilkego i Prousta, przeł.

A. Przybysławski, Kraków 2004 (cytat: s. 22).

${ }^{25}$ Ta dziwna instytucja..., s. 190-191.
} 
Lektura transcendentna jest niemożliwa, gdyż nie ma wyjścia z tekstualnej siatki, w jaką uwikłane są nasze interpretacje. Ale lektura transcendentna jest także konieczna, gdyż wszyscy czytamy, chcąc wyciagnąć $\mathrm{z}$ tekstu jakiś sens dla siebie. W ślad za tym double bind stara się podążać hermeneutyka ponowoczesna, która pragnie potraktować lekcję Derridy serio, uświadamiając sobie, że ów „sens” jest efektem samego tekstu, że właśnie nie można wyciagną́ (w sensie: wyjąć na zewnątrz) sensu $z$ tekstu, gdyż on zawsze znajduje się $w$ tekście, w archi-tekście: „To, co nazywam «tekstem», zakłada w sobie wszelkie tak zwane rzeczywiste, ekonomiczne, historyczne, socjoinstytucjonalne struktury, słowem: wszelkie możliwe typy odniesień. [...] Nie oznacza to, że wszystkie odniesienia są zawieszone, zanegowane lub zawarte w książce [...]. Oznacza to natomiast, że wszelkie odniesienie, wszelka rzeczywistość posiada strukturę różnicującego śladu i że odnosić się do tej «rzeczywistości» można jedynie za pomocą doświadczenia interpretującego"26. A zatem nie: zaprzestanie jakiejkolwiek rozumiejącej lektury, ale, jak mówi Derrida: posuwanie rozumienia możliwie jak najdalej ${ }^{27}$.

\section{Kontrowersja Derrida-Gadamer: powtórzenie (z przemieszczeniem)}

Czy jednak po prześledzeniu tego kolizyjnego kursu myśli Derridy i Gadamera nie dałoby się spojrzeć na cały problem jeszcze raz, od nieco innej strony? Czy nie dałoby się powiedzieć, że jakiś „element” dekonstrukcyjny mieści się już w samym środku doświadczenia hermeneutycznego? Czy nie to ma na myśli Richard E. Palmer, członek tzw. grupy Spanosa zajmującej się wypracowaniem postmodernistycznej hermeneutyki literackiej opartej na myśli Heideggera ${ }^{28}$, gdy twierdzi, że „skupienie się wyłącznie na pozytywności tego, co tekst mówi explicite, oznacza niewypełnienie hermeneutycznego zadania”, zaś „opory przed czynieniem "gwałtu na tekście» nie mogą stać się usprawiedliwieniem odwrotu od [tego] hermeneutycznego zadania"29? Czyż w stronę tego dekonstrukcyjnego bieguna nie wychyla się Ricoeur, kiedy wprost powiada, że „pismo, a zwłaszcza struktura dzieła, modyfikuje referencję do tego stopnia, że staje się ona problematyczna”, tak że „rozumienie jest [...] w tej samej mierze oddaleniem się co przyswojeniem. Można zatem, a nawet trzeba, włączyć w rozumienie siebie krytykę złudzeń podmiotu"30? Czy wreszcie poza eksplicytnościq tekstu nie dałoby się wskazać na kilka zasadniczych pokrewieństw myśli Derridy i Gadamera ${ }^{31}$ ? Spróbujmy je scharakteryzować.

Wydaje się, że u autora Marginesów filozofii odnaleźć można swoiste powtórzenie (przy czym byłoby to powtórzenie z przemieszczeniem, iteracja) schematu dialogu między tekstem i czytelnikiem jako nieustannej wymiany pytań i odpowiedzi. Derrida przepisuje go oczywiście na swój język, mówiąc o „sygnaturze” autora/tekstu i dopisywanej do niej „kontrsygnaturze” czytelnika. W obu przypadkach mamy jednak do czynienia z podobną ontologią dzieła literackiego, które istnieje (tzn. jest aktualizowane) jedynie w procesie interpretacji. I choć aktualizacja ta odbywa się na różne sposoby (bardziej „ekumeniczny” dialog u Gadamera, bardziej „agonistyczna” wymiana u Derridy), to zaryzykować można ostrożną tezę, że obok koła hermeneutycznego dałoby się mówić o specyficznym

${ }^{26}$ J. Derrida, Limited Inc., przeł. S. Weber, J. Mehlman, Evanstone 1988, s. 148 (cytat w tłumaczeniu M.P. Markowskiego).

${ }^{27}$ Zob. J. Derrida, Ostrogi..., s. 94.

${ }^{28}$ Zob. na ten temat np. N. Leśniewski, O hermeneutyce radykalnej, Poznań 1998, s. 35-40.

${ }^{29}$ R.E. Palmer, Manifest hermeneutyczny (fragmenty), przeł. M. Król, W. Lubowiecki, „Pamiętnik Literacki” 1992, nr 1, s. 158-159.

${ }^{30}$ P. Ricoeur, Hermeneutyczna funkcja dystansu, przeł. P. Graff, [w:] Współczesna teoria badań literackich za granica. Antologia, t. 4, cz. 1, oprac. H. Markiewicz, Kraków 1996, s. 163, 167.

${ }^{31}$ Por. też mój tekst: P. Szaj, Czy można pogodzić dekonstrukcję z hermeneutykq̨? Dialog Derridy z Gadamerem, „Czas Kultury" 2014, nr 5. 
(„zwichniętym”, bo pozbawionym wymiaru całościowego) kole dekonstrukcyjnym, gdzie także chodzi przecież o swoistą odpowiedź na wezwanie tekstu: „zawsze piszę w odpowiedzi na zaproszenie lub prowokację", ale „moja odpowiedź na zaproszenie nigdy nie jest mu całkowicie posłuszna”"32. W tej „prowokacji” usłyszeć chyba trzeba pro-vocatio, wezwanie skierowane tylko do mnie samego, wzywające do udzielenia twórczej odpowiedzi, do dopisania do idiomu tekstu własnej idiomatycznej sygnatury. Jak wiadomo, Derrida mówi w takim przypadku o inwencji ${ }^{33}$, ale czy nie znajdujemy się tu - nadal - bardzo blisko Gadamera, dla którego „rozumieć” to zawsze „rozumieć inaczej”?

Warto także raz jeszcze podkreślić ambiwalencję tekstu Gadamerowskiego, który - choć stawia przed interpretatorem zadanie rekonstrukcji i integracji sensu dzieła literackiego, to jednocześnie nigdy nie twierdzi, że takie scałościowanie jest bezproblemowe. Przeciwnie, zastanowić by się należało, czy na gruncie hermeneutyki Gadamera w ogóle kiedykolwiek do niego dochodzi. Sam autor Prawdy i metody równie często mówi raczej o „nadwyżce” sensu, o „porażeniu przez sens tego, co powiedziane” ${ }^{34}$, które destruuje jakiekolwiek „oczekiwanie sensu”. I znów: czy nie dałoby się tutaj usłyszeć swoistego odpowiednika Derridiańskiego „nadmiaru signifiants" podważającego jakiekolwiek zabiegi mające na celu zabezpieczenie gry znaczeń? Jeśliby odpowiedzieć na to pytanie twierdząco, to w koncepcji „śladu” Derridy upatrywać należałoby po prostu radykalizacji tez hermeneutyki nowoczesnej (Gadamera, ale też Michaiła Bachtina) o dialogiczności rozumienia. I tu, i tu mowa bowiem o tym, że wszelkie rozumienie odbywa się we wspólnocie - we wspólnocie ludzi i znaków, których wzajemna wymiana nie ma końca.

W tym miejscu następuje jednak zerwanie. Bo choć „ślad” ująć można jako radykalizację „dialogiczności”, to - jak zauważa John D. Caputo - „prawo” to nie działa w odwrotną stronę: sama „dialogiczność”, przynajmniej pojęta na sposób Gadamerowski, nie dopuszcza logiki „śladu”35. Dlatego autor Radical Hermeneutics twierdzi, że ontologie dzieła sztuki Derridy i Gadamera mimo wszystko istotnie się od siebie różnią - podczas gdy „ślad” Derridy odsyła jedynie do innych „śladów” (zwichnięte koło dekonstrukcyjne), „fragment” Gadamera konotuje istnienie całości (koło hermeneutyczne): „Fragment Gadamerowski jest symbolem, który należy dopasować do jego brakującej, idealnie się z nim komponującej połowy, znakiem, poprzez który rozpoznajemy nieskończoność, całość [the whole], świętość [the holy]. Dekonstrukcyjne ślady to [...] symbolon, który został roztrzaskany na zbyt wiele części, aby można go było złączyć w całość, który w istocie nigdy nie był całością"36.

\section{„Posunąć rozumienie możliwie jak najdalej” - hermeneutyka po dekonstrukcji}

Jako się rzekło, hermeneutyka ponowoczesna stara się potraktować lekcję Derridy serio, a nawet wprost z niej wyrasta. Caputo mówi w tym kontekście, że dekonstrukcja jest „bramą", przez którą musi przejść hermeneutyka, aby powrócić do siebie w mniej niewinny, mniej

\footnotetext{
${ }^{32}$ Ta dziwna instytucja..., s. 186.

${ }^{33}$ Zob. np. J. Derrida, Psyche. Odkrywanie innego, przeł. M.P. Markowski, [w:] Postmodernizm. Antologia przekładów, red. R. Nycz, Kraków 1997.

${ }^{34}$ Zob. H.-G. Gadamer, Estetyka i hermeneutyka, s. 138-139.

${ }^{35}$ Zob. J.D. Caputo, More Radical Hermeneutics: On Not Knowing Who We Are, Bloomington-Indianapolis 2000, s. 53.

${ }^{36}$ Tamże, s. 50. Na odmienność ontologii dzieła sztuki Derridy i Gadamera zwraca także uwagę Dybel, który zauważa, że wynika ona z poruszania się w odmiennych porządkach: „znaczącego” („ślad”, o którym mówi Derrida) i „znaczonego” („Rzecz”, o której mówi Gadamer) (zob. P. Dybel, Granice rozumienia..., s. 457-463).
} 
naiwny sposób ${ }^{37}$. Ale konieczność przejścia przez tę bramę wynika nie tylko z chęci dalszego uprawiania hermeneutyki po dekonstrukcji, lecz również z zauważenia fundamentalnego hermeneutycznego aspektu samej dekonstrukcji: „nie ma hermeneutycznego odnalezienia siebie [recovery] bez dekonstrukcji”, ale też „nie ma dekonstrukcji, której celem nie byłoby odnalezienie siebie" ${ }^{38}$. Doświadczenie hermeneutyczne pojęte jako „pierwotna” sytuacja rzucenia w świat (choćby świat tekstu) i pragnienia odnalezienia się w tym świecie tkwi bowiem $w$ środku doświadczenia dekonstrukcyjnego, tak że samą dekonstrukcję pojąć można już jako hermeneutykę - hermeneutykę radykalną ${ }^{39}$, tzn. zachowującą uczciwość wobec znaczeniorodnej struktury wszelkiego znaku, stawiającą przed sobą imperatyw niezakłamywania swej „rzeczywistej”, przygodnej, chwiejnej kondycji nieufundowanej w żadnym „transcendentalnym signifié", zdającej sprawę z tego, że - jak powiada Michał Paweł Markowski - wszelkie rozumienie jest „zarażone nie-rozumieniem” ${ }^{\text {. }}$.

Lekcja, jaką hermeneutyka ponowoczesna czerpie z dekonstrukcji, polega więc przede wszystkim na baczniejszym zwracaniu uwagi na tekstualność (resp. znakowość) tekstu. Choć była ona dostrzegana już przez niektóre nurty hermeneutyki nowoczesnej (szczególnie przez Ricoeura), to jednak w koncepcjach Heideggera czy Gadamera, jak zauważa np. Wojciech Kalaga, po prostu jej brakuje ${ }^{41}$. Hermeneutyka ponowoczesna stara się nadrobić ten semiotyczny deficyt, zaś jednym z reprezentatywnych projektów jest tu tzw. semiologia hermeneutyczna Hugh J. Silvermana, wynikająca z przekonania, że tekst stanowi swoisty fenomen działający na przecięciu semiotyki i hermeneutyki, w związku z czym „czytanie identyfikuje tekstualność dzieła literackiego, dekonstruuje tekst w taki sposób, że z jednej strony, znaki aktualizują znaczenia, a z drugiej,

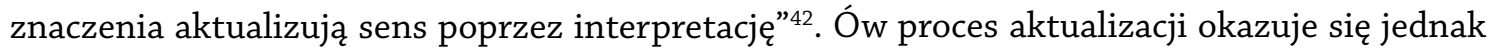
nigdy niezakończony, gdyż tekstualność to nie tylko swoista „praktyka tekstu”, ale i „warunek tekstu” decydujący o jego „śladowym” charakterze wynikającym z powiązania z innymi tekstami i z innymi znakami. Na podobny aspekt tekstualności zwraca także uwagę Caputo, którego hermeneutyka również „otwiera się” na logikę différance ${ }^{43}$ - to właśnie ta logika decyduje o „śladowości” tekstu i jego „zanieczyszczonym” charakterze. Jeśli bowiem każdy znak nosi w sobie jakby „wspomnienie” poprzedzających go znaków, a jednocześnie niejako „zapowiada” znaki, które przyją po nim, to następuje załamanie jego stabilnej tożsamości. Dlatego rację ma Dybel,

\footnotetext{
${ }^{37}$ Zob. J.D. Caputo, Radical Hermeneutics. Repetition, Deconstruction, and the Hermeneutic Project, BloomingtonIndianapolis 1987, s. 97.

${ }^{38}$ Tamże, s. 65.

${ }^{39}$ Por. D. Hoy, Jacques Derrida, [w:] Powrót wielkiej teorii w naukach humanistycznych, red. Q. Skinner, przeł. P. Łozowski, Lublin 1998, s. 60

${ }^{40} Z$ Zob. M.P. Markowski, Od rozumienia do nierozumienia, [w:] tegoż, Polityka wrażliwości. Wprowadzenie do humanistyki, Kraków 2013 (cytat: s. 233).

${ }^{41}$ W. Kalaga, Mgławice dyskursu. Podmiot, tekst, interpretacja, Kraków 2001, s. 49: „[...] brak w aparacie pojęciowym hermeneutyki koherentnej i metodologicznie aktywnej kategorii znaku. Hermeneutyka skupia się na zagadnieniach interpretacji, nie poświęcając jednocześnie większej uwagi najważniejszemu konstytutywnemu czynnikowi i medium procesów interpretacyjnych; bada ona mechanizmy interpretacji, pomijając leżącą u jej podstaw maszynerię" (zob. też cały rozdział Interpretacja i ontologia, w którym autor dokonuje ciekawej, komplementarnej wobec hermeneutyki ponowoczesnej, próby połączenia stanowisk hermeneutyki i semiotyki wobec zagadnienia interpretacji).

${ }^{42}$ H.J. Silverman, Textualities. Between Hermeneutics and Deconstruction, New York-London 1994, s. 73 (fragment w tłumaczeniu N. Leśniewskiego - por. też omówienie koncepcji Silvermana dokonane przez poznańskiego badacza: O tekstualności. Hermeneutyka semiologiczna Hugh J. Silvermana, [w:] tegoż, O hermeneutyce radykalnej).

${ }^{43}$ Zob. J.D. Caputo, Radical Hermeneutics..., s. 6.
} 
gdy twierdzi, że „każde znaczące jest sobą jedynie o tyle, o ile jest już poza sobą" ${ }^{4}$. „Modelowy przykład" takiego zanieczyszczenia stanowi zaś - jak mówi Caputo - literatura ${ }^{45}$.

Wszystko to nie oznacza jednak - ani dla Caputo czy Silvermana, ani dla samego Derridy zaprzestania jakichkolwiek hermeneutycznych wysiłków. Przeciwnie, rzec by można, że wysiłki te należy dodatkowo wzmóc, by - właśnie - posunąć rozumienie możliwie jak najdalej. Owo „możliwie jak najdalej” wskazuje, że w samym tekście znajdują się takie elementy, które w pewnym sensie zabezpieczają go "przed wszelkim pytaniem hermeneutycznym”, a nawet

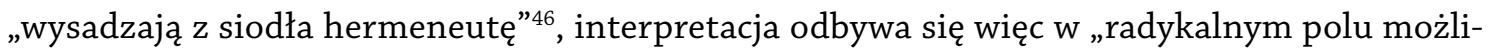
wego rozumienia" ${ }^{47}$, poza które nie sposób wyjść, jeśli chce się dochować tekstowi wierności. "Posunąć rozumienie możliwie jak najdalej” to zatem mieć świadomość, że logika différance bynajmniej nie wieńczy zabiegów hermeneutycznych, ale - przeciwnie - wręcz je wymusza, jednocześnie uniemożliwiając ich zakończenie: rozumienie okazuje się procesem nieskończonym, jeśli tylko bierze pod uwagę związany z différance „współczynnik niedookreślenia”48.

Czy zatem rację ma Michał Januszkiewicz, gdy twierdzi, że ponowoczesna radykalizacja hermeneutyki odbywa się pod znakiem intentio lectoris ${ }^{49}$ ? Wydaje się, że sprawa nie jest tak oczywista, albo nawet - że naznaczona jest fundamentalną nierozstrzygalnościq̨. Z jednej strony, czytelnik radykalnohermeneutyczny cechować się musi inwencyjnością, musi odpowiadać na tekst twórczo, a to znaczy, że istotnie wnosi on do tekstu własną perspektywę. $Z$ drugiej jednak, jak już widzieliśmy, to tekst „coś” mu mówi, niejako „wymusza” na nim respektowanie jego skomplikowanych gier tekstualnych, nie dopuszcza całkowitej swobody interpretacyjnej, ale „blokuje” też interpretacje zbyt upraszczające jego wymowę, a chcące uchodzić za koherentne, całościowe i adekwatne. Interpretacja radykalnohermeneutyczna nie jawi się więc ani jako adekwatnościowa, ani jako konstruktywistyczna - jak zauważa Norbert Leśniewski, mieści się ona pomiędzy tymi dwoma biegunami, oba je zresztą przekraczając ${ }^{50}$. Dlaczego tak się dzieje? Spróbujmy przyjrzeć się sprawie dokładniej.

\section{Śledzenie śladu - ontologia tekstu, ontologia lektury}

Radykalnohermeneutyczna ontologia tekstu to oczywiście ontologia „słaba” (w sensie Vattimowskim): nie pyta o to, czym jest tekst-w-sobie, ale o to, co się w tekście dzieje, czym jest tekst jako wydarzenie, jako specyficzny fenomen dany jedynie w doświadczeniu lekturowym. Traktuje go zatem jako coś nieskończonego, tzn. otwartego semantycznie i strukturalnie, podatnego na rekontekstualizacje. Wszelkie dzieło literackie z perspektywy radykalnohermeneutycznej utożsamić można z „sylwą" - tekstem wystawionym na możliwość dalszego rozwoju i czytelnicze strukturyzacje, swoistą, jak mówi Ryszard Nycz, „partyturą oczekującą lekturowego

\footnotetext{
${ }^{44}$ P. Dybel, Oblicza hermeneutyki, s. 42.

${ }^{45}$ Zob. J.D. Caputo, Prayers and Tears of Jacques Derrida. Religion without Religion, Bloomington-Indianapolis 1997, s. 52.

${ }^{46}$ Zob. J. Derrida, Ostrogi..., s. 91, 94.

${ }^{47}$ Określenie N. Leśniewskiego, O hermeneutyce radykalnej, s. 225.

${ }^{48}$ Tamże, s. 224.

${ }^{49}$ Zob. M. Januszkiewicz, W-koło hermeneutyki literackiej, Warszawa 2007, s. 19-21.

${ }^{50} Z$ ob. N. Leśniewski, O hermeneutyce radykalnej, s. 48-57 (choć zauważyć można, że poznański badacz powiela błąd wielu interpretatorów, zarzucając Derridzie dowolność interpretacyjną).
} 
«wykonania»". O ile jednak sylwa stanowiłaby pewien „modelowy” przykład tekstu radykalnohermeneutycznego, przejaw „wyższej hermeneutycznej świadomości” współczesnej literatury (tym bardziej że sam Nycz zauważa, iż podmiot sylw niejako porusza się po „hermeneutycznym kręgu" ${ }^{51}$ ), o tyle jedynie uwydatniałaby cechy immanentnie przynależne wszystkim tekstom.

Tekst pojmowany jest bowiem w hermeneutyce ponowoczesnej nie tyle jako ergon (dzieło w sensie klasycznym), ile jako energeia - działanie o wyraźnym rysie performatywnym. Takie myślenie obecne jest zresztą także w hermeneutyce nowoczesnej, o czym wspomina Januszkiewicz ${ }^{52}$ czy implicytnie - Katarzyna Rosner, gdy twierdzi, że „znaczenie tekstu nie jest czymś gotowym, zamkniętym w tekście i wymagającym rozpoznania. Znaczenie tekstu powstaje w toku interpretacji, przez przyswojenie go, tzn. odniesienie zawartego w nim przekazu do naszej sytuacji egzystencjalnej, wyposażenie w referencję do naszego świata. Tylko dzięki przyswojeniu [...] tekst przemawia do nas, przekazuje nam swoją prawdę" ${ }^{\text {"3 }}$. Hermeneutyka ponowoczesna zachowuje ten pogląd, ale jednocześnie osłabia jego „prawdziwościowe” roszczenia, nieufnie podchodząc do takich kwestii, jak „przyswojenie”, „zawarty w tekście przekaz” czy „referencja”. Na performatywność Gadamerowską (dzieło literackie mówi: to jesteś ty, musisz zmienić swoje życie) odpowiada performatywnością zgoła derridiańską (dzieło literackie mówi czasem: nie ma żadnego ty - oto ty! $!^{54}$ ) - nie ma żadnego „ty”, gdyż „ty” stanowi dopiero efekt lektury, jest przez tekst jakby, by posłużyć się paradoksem, performatywnie konstatowane, powoływane do istnienia. Krótko mówiąc: tożsamość czytelnika jest tożsamością relacyjną. Sam tekst zaś okazuje się „obszarem spotkania potencjalności i aktualności” ${ }^{55}$ - wzajemnej wymiany śladów, która prowadzić może w najrozmaitszych kierunkach (biegun konstruktywistyczny), oraz czytelniczych konkretyzacji, które zawsze jakoś przykrawają, wstrzymują, stabilizują tę znaczeniorodną grę, przedkładając pewne ślady nad inne (biegun adekwatnościowy) ${ }^{56}$.

Jeśli jednak tekst pojmowany jest jako ślad, albo raczej skupisko śladów, to pamiętać należy, że ślad znaczy niejako poza wszelką intencją znaczącą. Oznacza to - na co już wskazywałem - że hermeneutyka ponowoczesna wprawdzie żegna się z pojęciem intentio operis (a tym bardziej $\mathrm{z}$ intentio auctoris), ale nie $\mathrm{z}$ samym pojęciem tekstu, przy czym nie traktuje go już substancjalnie, ale jako każdorazowo odnawiający się (energeia) efekt gry śladów. Jak zatem rozumieć postulat „trzymania się blisko tekstu” w hermeneutyce ponowoczesnej? Byłoby to swoiste „śledzenie śladów”, albo też - jak pisze Andrzej Zawadzki - „naśladowanie, kroczenie po śladach, tropienie ich i odczytywanie, odpowiadanie na nie własnym śladem" ${ }^{57}$. Słowem: kroczenie po

\footnotetext{
${ }^{51}$ Zob. R. Nycz, Wspótczesne sylwy wobec literackości, [w:] Problemy teorii literatury. Seria 3, red. H. Markiewicz, Wrocław 1988 (pierwszy cytat: s. 292, drugi cytat: s. 283).

${ }^{52}$ Zob. M. Januszkiewicz, W-koło hermeneutyki literackiej, s. 60.

${ }^{53} \mathrm{~K}$. Rosner, Hermeneutyczny model obcowania z tekstem literackim, [w:] Problemy teorii literatury. Seria 4, red.

H. Markiewicz, Wrocław 1998, s. 300. Przywołać by tu można także słowa, cytowanego już, Palmera: „znaczenie nie jest obiektywną, wieczną ideą, ale czymś, co pojawia się we wzajemnej relacji”. R. Palmer, Manifest hermeneutyczny..., s. 153.

${ }^{54}$ Zob. J.D. Caputo, More Radical Hermeneutics..., s. 55.

${ }^{55}$ W. Kalaga, Mgławice dyskursu..., s. 227.

${ }^{56}$ Język fenomenologiczny jest tu nie od rzeczy: myśl Derridy wyrasta z tradycji fenomenologicznej, co ujawnia się być może najwyraźniej właśnie w jego przekonaniach na temat procesu interpretacji tekstu literackiego. W rozmowie z Derekiem Attridgem mówił on: „Myślę, że język fenomenologiczny jest tu konieczny, nawet jeśli w pewnym punkcie sytuacja pisania i czytania [...] wprowadza [...] fenomenologię [...] w stan kryzysu" (Ta dziwna instytucja..., s. 190).

${ }^{57}$ A. Zawadzki, Literatura a myśl słaba, Kraków 2009, s. 157.
} 
śladach tekstu i podążanie w ślad za ich znaczeniorodną grą, przy jednoczesnej świadomości, że każda re-prezentacja jest de-prezentacją, że każdorazowo możemy znosić nieokreśloność znaczenia jedynie pod pewnym względem ${ }^{58}$. Tekst bowiem, jako splot (od łac. texere) tekstualnych fałd, warstw, zagięć, warunkuje czytanie jako ich de-konstruowanie, tzn. od-wijanie ${ }^{59}$. Zdaniem Derridy jednak praca ta pozostać musi nieskończona, gdyż fałda czy też zmarszczka - le plí60 - jest tym „elementarnym” elementem tekstu, który uniemożliwia jego semantyczne zamknięcie. Niemożliwa okazuje się więc pełna eks-pli-kacja znaczenia tekstu, w sensie: wygładzenie wszystkich jego fałd. Dla hermeneutyki jest to oczywiście źródło dramatu. Ale jest to także - po prostu - warunek możliwości uprawiania jakiejkolwiek hermeneutyki: gdyby wszystkie tekstualne fałdy dawały się bezproblemowo „odwinąć”, hermeneutyka w ogóle nie byłaby potrzebna. Dlatego należy uczciwie utrzymać to prawo tekstualności w mocy.

Szczeliny tekstu nie tylko więc nie dopuszczają "dowolnej” interpretacji, ale wręcz wymuszają na czytelniku wiernq mikrolekturę: „Istnieje «system» i istnieje tekst, w tekście zaś - szczeliny i zasoby, które nie dają się opanować przez systematyczny dyskurs [...]. Stąd też konieczność nieustannej, aktywnej interpretacji, zaangażowanej niczym skalpel w mikrobiologię, usilnej i za-

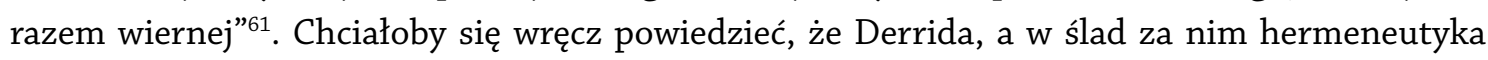
ponowoczesna, proponuje swoistą strategię close reading, która jest uważna (close), ale tym różni się od metody wypracowanej przez szkołę New Criticism, że nie jest zamknięta (close), lecz otwarta na wszelkie konteksty, jakie formaliści amerykańscy starali się wyeliminować. Tekst bowiem nie stanowi skończonej całości, ale - jak powiada Kalaga - ,jest «rozwiązły»”62. Aktualizując go, muszę brać pod uwagę wszystkie dostępne mi narzędzia analityczne, ale wykonuję tę pracę analityczną zawsze ze względu na siebie, akcentując to, co mnie w danym tekście wiąże, dotyka bądź porusza, i siłą rzeczy dopuszczając utratę innych znaczeń. W tym sensie rozumienie nigdy nie jest pełne, i wynika to zarówno ze skończoności interpretatora, jak i ze „śladowej” struktury znaku.

Ta radykalnohermeneutyczna wierność tekstowi byłaby zatem wiernością... niewierną. Jeśli dla Derridy każde znaczące jest sobą, o ile jest już poza sobą, to na poziomie interpretacji odpowiada temu pewna „zdrada” tekstu: zdradza się tożsamość znaku jako coś oznaczającego, ale zdradza się po to, aby mógł znaczyć dalej, aby nie zabezpieczać jego gry, aby nie u-toż-samiać się z nim w jakiejś tautologicznej interpretacji, ale oddać szacunek jego inności. Dlatego Januszkiewicz powie, że „twórcza niewierność” wobec tekstu „jest właśnie wiernością par excellence" ${ }^{\prime 63}$, a wynika ona $-\mathrm{z}$ jednej strony - ze swoistego double bind (tekst chce zakomunikować jakiś sens, a jednocześnie nie może powiedzieć nic jednoznacznego), z drugiej zaś z modelu czytania jako „pojedynku jednostkowości”, w którym kontrsygnatura tyleż potwierdza, powtarza sygnaturę innego, co „wyprowadza ją gdzieś indziej”, iterując tekst „pierwotny”,

\footnotetext{
${ }^{58}$ Por. N. Leśniewski, O hermeneutyce radykalnej, s. 201, 203.

${ }^{59}$ Zob. J.D. Caputo, Deconstruction in a Nutshell..., s. 88.

${ }^{60}$ Por. wywód na temat fałdki / zmarszczki / złożenia (le pli) M.P. Markowskiego, Efekt inskrypcji. Jacques Derrida i literatura, Bydgoszcz 1997, s. 261-267.

${ }^{61}$ Rozmowa Christiana Descampes'a z Jacques'em Derrida, [w:] Derridiana, wybór i oprac. B. Banasiak, Kraków 1994, s. 14. Por. też omówienie tego zagadnienia przez A. Burzyńską, Lekturografia. Derridowska filozofia czytania, [w:] tejże, Anty-teoria literatury.

${ }^{62}$ W. Kalaga, Mgławice dyskursu..., s. 222.

${ }^{63}$ Zob. M. Januszkiewicz, Hermeneutyka jako miejsce spotkania filozofii i literatury, [w:] tegoż, Kim jestem ja, kim jesteś ty? Etyka, tożsamość, rozumienie, Poznań 2012 (cytat: s. 83).
} 
wydobywając zeń jakąś „prawdę” dla siebie ${ }^{64}$. Jeśli więc miałaby tu być mowa o korespondencji między tekstem a interpretacją, to tylko w sensie „odpowiedzialnej odpowiedzi”, ko-respondencji, współ-odpowiadania sobie nawzajem, współ-odpowiedzialności za sens.

\section{Dotkliwość}

Wydaje się, że zaryzykować można opis radykalnohermeneutycznej relacji z tekstem za pomocą metafory dotkliwości ${ }^{65}$. Słowo to wskazywałoby - z jednej strony - na nieobojętność interpretacji, na swoiste bycie dotkniętym przez czytany tekst, na żywą relację z nim, z drugiej zaś - na jednostkowość doświadczenia tekstu, na wydarzeniowy (w sensie: niepowtarzalny, jedyny w swoim rodzaju) charakter interpretacji, w którą czytelnik jest zaangażowany egzystencjalnie. Wskazywałoby jednak także na dotkliwą niemożność scałościowania wyników interpretacji, dotkliwą wieloznaczeniowość tekstu, która nie poddaje się zabiegom hermeneutycznym.

Takie rozumienie dotkliwości odnaleźć można - jak sądzę - zarówno u Gadamera, jak i u Derridy. Jak pamiętamy, pierwszy z nich opisywał doświadczenie tekstu literackiego jako „porażenie przez sens tego, co powiedziane”, które nie prowadzi do harmonijnego skupienia sensu, ale przekracza jakikolwiek horyzont oczekiwań. W niemieckim oryginale „porażenie” to zostało określone jako Betroffenheit, w którym to słowie słychać także czasownik treffen - trafiać, i jego stronę bierną: betroffen werden - być trafionym, ugodzonym, uderzonym. Do zmysłu dotyku i problemu dotkliwości dzieła sztuki odwołuje się także zaczerpnięte od Heideggera pojęcie „pchnięcia” (Stoß), jakiego zdaniem Gadamera miałby doświadczać czytelnik ze strony szczególnie nań oddziałującego dzieła. Także to „pchnięcie” nie odpowiada harmonijnie na oczekiwanie sensu, ale prowadzi raczej do bolesnego „zerwania” ${ }^{66}$. Analogiczne określenia odnajdujemy u Derridy, który mówi o doświadczeniu lektury jako o „dotkliwej próbie”67 (ale też, co istotne, cielesnym „pożądaniu”). Próba ta jest dotkliwa, gdyz - jak czytamy gdzie indziej - „nie ma poematu, który nie otwierałby się jak rana, i sam nie byłby raniący" ${ }^{68}$, który zatem z jednej strony nie wystawiałby się na czytelnicze ingerencje, a z drugiej - sam nie ingerowałby boleśnie w świat czytelnika.

Wydaje się, że kategoria dotkliwości ma kilka istotnych zalet. Po pierwsze, wskazuje, że hermeneutyczne „rozumienie” nie jest - wbrew pozorom - czynnością czysto intelektualną, ale ma także wymiar cielesny, biorą w nim udział afekty, nastrój, określone „nastawienie” czytelnika. W tym sensie nie miała racji np. Susan Sontag, gdy postulowała zastąpienie hermeneutyki „erotyką sztuki” ${ }^{69}$, gdyż rozumienie jak najbardziej może (choć nie musi) być nastawione

${ }^{64}$ Zob. Ta dziwna instytucja..., s. 218-219. Por też: D. Attridge, Czytanie i opowiadanie, [w:] tegoż, Jednostkowość literatury, przeł. P. Mościcki, Kraków 2007.

${ }^{65}$ Por. mój artykuł Dotkliwe wiersze Aleksandra Wata, który stanowi próbę wykorzystania kategorii „dotkliwości” w praktyce interpretacyjnej (artykuł znajduje się w tece redakcyjnej „Pamiętnika Literackiego”, zostanie opublikowany w jednym z najbliższych numerów czasopisma).

${ }^{66}$ Określenie pochodzi z tekstu Gadamera Und dennoch: Macht des guten Willens (cyt. za: P. Dehnel, Dekonstrukcja a hermeneutyka, s. 88).

${ }^{67}$ Ta dziwna instytucja..., s. 197.

${ }^{68}$ J. Derrida, Che cos’è la poesia?, przeł. M.P. Markowski, „Literatura na Świecie” 1998, nr 11-12, s. 159.

${ }^{69}$ Zob. S. Sontag, Przeciw interpretacji i inne eseje, przeł. M. Pasicka, A. Skucińska, D. Żukowski, Kraków 2012. Z podobnych powodów za nietrafną uznaję diagnozę Izabelli Bukraby-Rylskiej, jakoby we współczesnej humanistyce dokonywało się przejście od „hermeneutycznego «rozumienia» do somatycznego «doświadczenia»", gdyż rozumienie samo w sobie jest już takim „somatycznym doświadczeniem” (zob.

I. Bukraba-Rylska, Humanistyka współczesna. Od hermeneutycznego „rozumienia” do somatycznego „doświadczenia”, „Kultura Współczesna” 2015, nr 2). 
erotycznie. Czytelnik jest czytelnikiem z krwi i kości, jego ciało tak czy owak bierze udział w procesie interpretacji, nawet jeśli dany hermeneuta nie będzie tego podkreślał.

Po drugie, w perspektywie tej „trzymać się blisko tekstu” oznaczałoby właśnie być wrażliwym na jego dotkliwość, tzn. - jak mówi Andrzej Sosnowski - pozwolić mu „wdać się w moje znaki”, a jednocześnie pozwolić, aby „dawał się on we znaki”, aby więc mógł jakoś mnie naznaczyć, pozostawić we mnie po sobie jakiś ślad, i aby ślad ten odciskał rzeczywiste piętno, nie dawał mi spokoju, uniemożliwiał jego neutralizację ${ }^{70}$. Tak pojęta dotkliwość działałaby jednak również w drugą stronę: jeśli tekst wdaje się w moje znaki/daje mi się we znaki, to - jak komentuje koncept Sosnowskiego Markowski - i ja ,jakoś [...] narzucam siebie temu, co czytam”, tak że możemy tu mó-

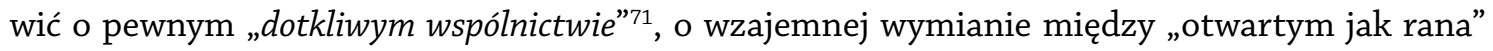
i „raniącym” tekstem a „wczytującym się w tekst” i „wczytującym siebie w tekst” czytelnikiem².

Po trzecie wreszcie, dotkliwość jawiłaby się jako kategoria „nierozstrzygalna”: z jednej strony podkreślałaby bolesność bycia ugodzonym przez tekst, z drugiej - wskazywałaby też na pewną intymność, a nawet erotyzm, do-tkliwość relacji z tekstem. Z jednej strony mówiłaby, że to tekst boleśnie mnie naznacza, z drugiej - że to ja w tekst ingeruję, dopisując do niego swoją kontrsygnaturę. Wszystko bowiem dzieje się w tym przecięciu, w tym punkcie spotkania, w tym inter-esse, w tym chiazmie, w tej „relacji między dwoma doświadczeniami, dwoma zdarzeniami lub dwoma językami polega[jącej] na podwójnej inwaginacji"73. I właśnie tę figurę chiazmu potraktować by można jako zradykalizowaną (co znaczy tu: osłabioną) figurę fuzji horyzontów.

${ }^{70} Z$ Zob. A. Sosnowski, Ostatnia miłość literatury, „Literatura na Świecie” 1998, s. 11-12.

${ }^{71}$ M.P. Markowski, Od rozumienia do nierozumienia, s. 260-261.

${ }^{72}$ Odwołuję się tu do propozycji M. Januszkiewicza (Wczytywanie (się) w tekst. O interpretacji transakcyjnej. [w:] tegoż, Kim jestem ja, kim jesteś ty?...), zgodnie z którą interpretacja jest zawsze pewną transakcją: wczytując się w tekst (tzn. w to, co tekst ma mi do powiedzenia), jednocześnie wczytuję w tekst siebie (tzn. wchodzę do świata tekstu z bagażem własnych przedsądów, doświadczeń, światopoglądu itp., ze względu na które dokonuję interpretacji).

${ }^{73}$ J. Derrida, Parages, Paris 1986, s. 196 (cyt. za: M.P. Markowski, Efekt inskrypcji..., s. 368; por. też interpretacja figury chiazmu dokonana przez Markowskiego w zmieszczonym w tej książce rozdziale Chiazm). 


\title{
SEOWA KLUCZOWE:
}

\author{
GADAMER \\ i n t e r p r e t a c ja \\ hermeneutyka
}

\begin{abstract}
Abstrakt:
Artykuł omawia podejście do tekstu i procesu interpretacji, z jakim mamy do czynienia na gruncie hermeneutyki ponowoczesnej (radykalnej). Rozpoczyna go omówienie pojęcia tekstu wypracowanego przez Hansa-Georga Gadamera, które następnie zderzone zostaje z krytyką, jaką poddał hermeneutyce Jacques Derrida. Po rekapitulacji obu stanowisk zauważone zostaje jednak pewne niespodziewane podobieństwo pomiędzy Gadamerowskimi a Derridiańskimi przeświadczeniami na temat „ontologii” dzieła literackiego i „natury” procesu interpretacji. Hermeneutyka ponowoczesna z jednej strony podobieństwo to dostrzega, z drugiej zaś - stara się potraktować „lekcję dekonstrukcji” serio, zwracając baczniejszą uwagę na tekstualność tekstu, jego śladowość, nieskończoną grę znaczeń, która uniemożliwia zakończenie, scałościowanie, spełnienie jakichkolwiek zabiegów hermeneutycznych. Trzymanie się blisko tekstu na gruncie hermeneutyki ponowoczesnej polega więc na swoistym „śledzeniu śladów” - podążaniu za znaczeniorodną grą tekstu i dopisywaniu do niej twórczej kontrsygnatury czytelniczej. W zakończeniu artykułu zaproponowana zostaje metafora „dotkliwości” jako pojęcia trafnie oddającego radykalnohermeneutyczną relację z tekstem.
\end{abstract}




\title{
Caputo
}

\section{dekonstrukcja}

\author{
tekst
}

\section{DERRIDA}

\section{NOTA O AUTORZE:}

Patryk Szaj - doktorant na Wydziale Filologii Polskiej i Klasycznej Uniwersytetu im. Adama Mickiewicza w Poznaniu. Interesuje się teorią literatury, związkami literatury z filozofią, hermeneutyką ponowoczesną. Publikował m.in. w „Analizie i Egzystencji”, „Czasie Kultury”, „Czytaniu Literatury”, „Internetowym Magazynie Filozoficznym Hybris”, „Kulturze Współczesnej”, „Literaturoznawstwie”. Stypendysta Fundacji Uniwersytetu im. Adama Mickiewicza w Poznaniu w roku akademickim 2015/2016. 